\title{
Pricing Natural Gas in Mexico: \\ an Application of the Little-Mirrlees Rule
}

Dagobert L. Brito*

Juan Rosellón**

November, 2000

\begin{abstract}
The Comisión Reguladora de Energía has implemented a netback rule for linking the Mexican market for natural gas with the North American market. This paper describes the economic analysis that supported this policy. We show that the netback rule is the efficient way to price natural gas and it is in fact an application of the Little-Mirrlees Rule. We also study the implications of this new regulatory framework on Pemex's marketing activities in the forward market for gas. We argue that PEMEX should be permitted to enter into spot contracts or future contracts to sell gas, however, the price of gas should always be the net back price based on the Houston Ship Channel at the time of delivery. This arrangement is transparent, it is easy to enforce and does not eliminate any legitimate market options for any of the parties involved. PEMEX or consumers of gas can use the Houston market for hedging of speculative transactions.
\end{abstract}

Key words; natural gas, welfare, pricing, Mexico, regulation

* Department of Economics and Baker Insitute[MS-22]

Rice University

6100 Main

Houston, TX 77005

email:brito@rice.edu

** Centro de Investigación y Docencia Económicas, A. C.

Carret. México Toluca 3655

Lomas de Santa Fe, 01210

Mexico D. F

e-mail:jrosellon@dis1.cide.mx

The research reported in this paper was supported by the Comisión Reguladora de Energía in a grant to the Centro de Investigacion y Docencia Economicas, A.C. We would like to thank William Laney Littlejohn and Peter Mieszkowski for their suggestions. 


\section{Introduction}

Mexico has an energy market that is different from most other countries. The national oil company, Petróleos Mexicanos (Pemex) is a very important political and symbolic institution. The oil industry was initially owned by foreign interests and its nationalization in 1938 is viewed by many as an expression of Mexican sovereignty. Privatization of Pemex is politically impossible.

Difficulties arise from three sources. First, Pemex is a monopoly and many of the markets involved are regulated. Prices in these markets are not a good guide for economic decisions as to production. Second, oil, gas and natural gas liquids are often produced jointly, and in such cases it is impossible to allocate costs of production to a specific product. ${ }^{1}$ Finally, the goods produced are substitutes in consumption. Gas and oil are substitutes in the generation of power; natural gas liquids, gas and oil are substitutes as feedstocks. This creates very difficult problems in regulating prices. The Comisión Reguladora de Energía (CRE) has been given the responsibility of regulating the price of natural gas. They solved the problem of pricing gas by using the Houston Ship Channel price as a benchmark.

The pricing rule based on the Houston Ship Channel price is an implementation of the Little-Mirrlees proposal for pricing traded goods. They propose using the world prices for traded goods, not necessarily because theses prices are more rational, but rather because these prices reflect the terms under which a country can trade. Thus the price of gas in Houston is a measure of the opportunity cost to Mexico of consuming the gas rather than exporting it to the United States. ${ }^{2}$

${ }^{1}$ See Adelman (1963) and Brito, et. al. (2000).

2.See Little and Mirrlees (1968) p. 92. There were two other proposals discussed as a way of pricing natural gas in Mexico. One was to use the cost of production and the other was to use the cost of substitutes for natural gas. The first suggestion is not possible as most natural gas in Mexico is produced as a joint product with oil and there is no well defined cost of production. There is not a free market in many of the substitutes for natural gas in Mexico so it is not possible to use these prices. Note that using the price of gas in Houston does this in as much as the price of gas in Houston reflects the price of competitive sources of energy. 
This pricing rule means that the price of gas in Mexico is insensitive to changes in the demand for gas in Mexico. Consumers of gas are facing a flat supply curve. The equilibrating factor is the amount of gas imported or exported. If the Little Mirrlees rule is implemented in Mexico, a question is what restrictions should be placed on Pemex's marketing activities in the natural gas market. To address this question, it is useful to review what are probably well accepted goals for regulation. These include the efficient allocation of resources, achieving some redistributive goals, simplicity and transparency. With these goals in mind, it is clear that the decision to link the price of natural gas in Mexico to the price at the Houston ship channel by a netback rule solves some very difficult technical and institutional problems in a very simple fashion. The netback rule links the price of gas at any point in Mexico to the price of gas in Houston adjusting for the cost of transportation. The natural gas market in Mexico then has all the properties of the gas market at Houston. In particular, all agents are price takers with respect to the market and the Houston market can be used by agents in Mexico for hedging and other forward contracts. The key to the implementation of this policy is that there is sufficient pipeline capacity so that the gas markets can clear and rents do not accrue to the pipelines. If there is not sufficient pipeline capacity so that the natural gas markets in Mexico can clear at the Houston netback prices, it is impossible to implement the netback rule. At the net back price, demand would be greater than supply.

A proposal that is being discussed is to change the system so that Pemex sells gas only at the point of injection. The prices in the local markets are set by local supply and demand conditions. These changes will create uncertainty in the gas market and also create the possibility of strategic manipulation of the price of gas that will be very difficult to regulate. Further, the current regulations permit the net back price to be an upper bound and Pemex can sell gas below that price if it does so in a nondiscriminatory fashion. The reason that has been given for allowing Pemex to sell at a price below the Houston netback price, as long as the sales were non discriminatory, is that there is no reason to restrict voluntary transaction between parties. However, there is a substantial agency problem in these transactions. It is hard to understand why Pemex (acting as a agent for the Mexican 
people) would want to sell gas in Mexico for less than it could net by selling the gas in Houston. There may be policy reasons to subsidize gas in certain circumstances; however, this does not seem like a decision that should be delegated to Pemex gas marketing

Pemex should be permitted to enter into spot contracts or future contracts to sell gas, however, the price of gas should always be the net back price based on the Houston Ship Channel at the time of delivery. Pemex should not be permitted to discount the price of gas from the Houston netback price even in a nondiscriminatory fashion. This arrangement is transparent, it is easy to enforce and does not eliminate any legitimate market options for any of the parties involved. Pemex or consumers of gas can use the Houston market for hedging of speculative transactions.

The Houston market can also serve as a buffer for fluctuations in Pemex's production or in demand. Pemex can vary its sales in the Houston market to smooth fluctuation in Mexico. This buffer allows Pemex to only sell "plain vanilla" gas without having to engage in complex market operations in Mexico. Thus, it is very difficult to see what useful role can be played by Pemex acting as a gas marketeer in Mexico. If Pemex wants to engage in speculative market behavior, it can do so in the Houston market. Houston has the advantage of being a well developed market. Pemex's transactions in that market would not create any regulatory issues for the CRE as long as Pemex sells gas in Mexico at the Houston spot netback price. As long as there is sufficient pipeline capacity so that there are no bottlenecks in transporting gas, this simple rule will result in an efficient and transparent natural gas market in Mexico.

Allowing Pemex discretion in pricing gas becomes an even more complicated problem if Pemex is allowed to sell gas for future delivery at a price other than the Houston netback price at the time of delivery. For example, Pemex can sell gas for delivery 30 days in the future at a given price and the next day sell gas for delivery 29 days in the future a different price. Technically, these transactions would not be discriminatory. Transactions that involve selling forward gas at a predetermined price would be very difficult to monitor and give Pemex gas marketeers a very large amount of power and discretion. 
There are important and legitimate reasons why private oil companies use forward markets to reduce risk; let us grant that such reasons may also apply a nation oil company such as Pemex. Restricting Pemex to sell gas in Mexico at the Houston spot market netback price does not eliminate any options for Pemex. Linking the price of gas in Mexico to the Houston market permits Pemex to operate in these sophisticated markets without involving their customers for gas delivered in Mexico. Further, buyers of natural gas in Mexico can enter into transactions in Houston without involving Pemex. Thus, there is no economic reason for Pemex has to operate as a gas marketeer in Mexico.

It may seem more efficient to permit Pemex and other parties involved to enter into such transactions directly without going through the Houston market. However, requiring such transactions to take place in the well developed Houston market reduces the possibility of fraud and also reduces the regulatory burden in Mexico.

In North America, gas is transported by pipeline. The cost of transporting 1000 cubic feet of gas 1000 miles by onshore pipeline is approximately $\$ .40$ to $\$ .85$. By contrast, the cost of transporting a barrel of residual fuel oil is approximately $\$ .10$ per thousand miles. Since a barrel of residual fuel oil has the energy equivalent of 6000 cubic feet of gas, gas is more than twenty times more expensive to transport than fuel oil. The economics of transportation is a key element in the North American market for gas. This market is based on pipelines and there are pipelines connecting the United States, Mexico and Canada.

We begin by considering the essentials of the Mexican pipeline system, and show how the price of natural gas in Mexico is tied to the gas prices in South Texas. We then construct a model of natural gas import, export and distribution in Mexico, and derive the optimal pricing rule of natural gas in the Mexican pipeline system. This pricing rule is the formula that the CRE has implemented and is consistent with the objectives of a regulator seeking to optimize social welfare. Finally, we analyze the impact on the price of Mexican natural gas of technical export restrictions, new points of production, and forward markets and restrictions on pipeline capacity. 


\section{The Mexican Natural Gas Market}

The Mexican pipeline system is shown in Figure 1. This network is 9,043 kilometer long. It reaches most of the industrial centers with the exception of the Northwest North Pacific part of the country. In 1994 the pipeline system transported 2.4 billion cubic feet of natural gas per day (bcfd). This volume includes 130 million cubic feet (Mmcfd) of gas imports, $140 \mathrm{Mmfcd}$ of non associated gas, and $2.1 \mathrm{bcfd}$ of associated gas from processing plants. As of 2000, 1795 kilometer of new private pipelines have been added to the existing transportation system and the capacity has increased to $7.4 \mathrm{bcfd}$. Mexico has approximately 78 trillion cubic feet of gas reserves (this is 45 years reserves at the present rate of consumption). In recent years over 38 trillion cubic feet of non associated gas have been discovered near Burgos. ${ }^{3}$ These gas fields are close to the Texas border. At present rate of consumption, this is over 35 years of reserves so there is a potential for this gas to be exported to the U.S. market. The pipeline linkage from these discoveries to the U.S. market is currently under expansion. ${ }^{4}$

\footnotetext{
3.Pemex, 1998.

4. The current export capacity at Reynosa is $175 \mathrm{Mmcfd}$ and the import capacity is 300 Mmcf per day. These capacities are being expanded to around 220 and $340 \mathrm{Mmfd}$ of capacity respectively with the Tennessee and Tejas pipelines.
} 


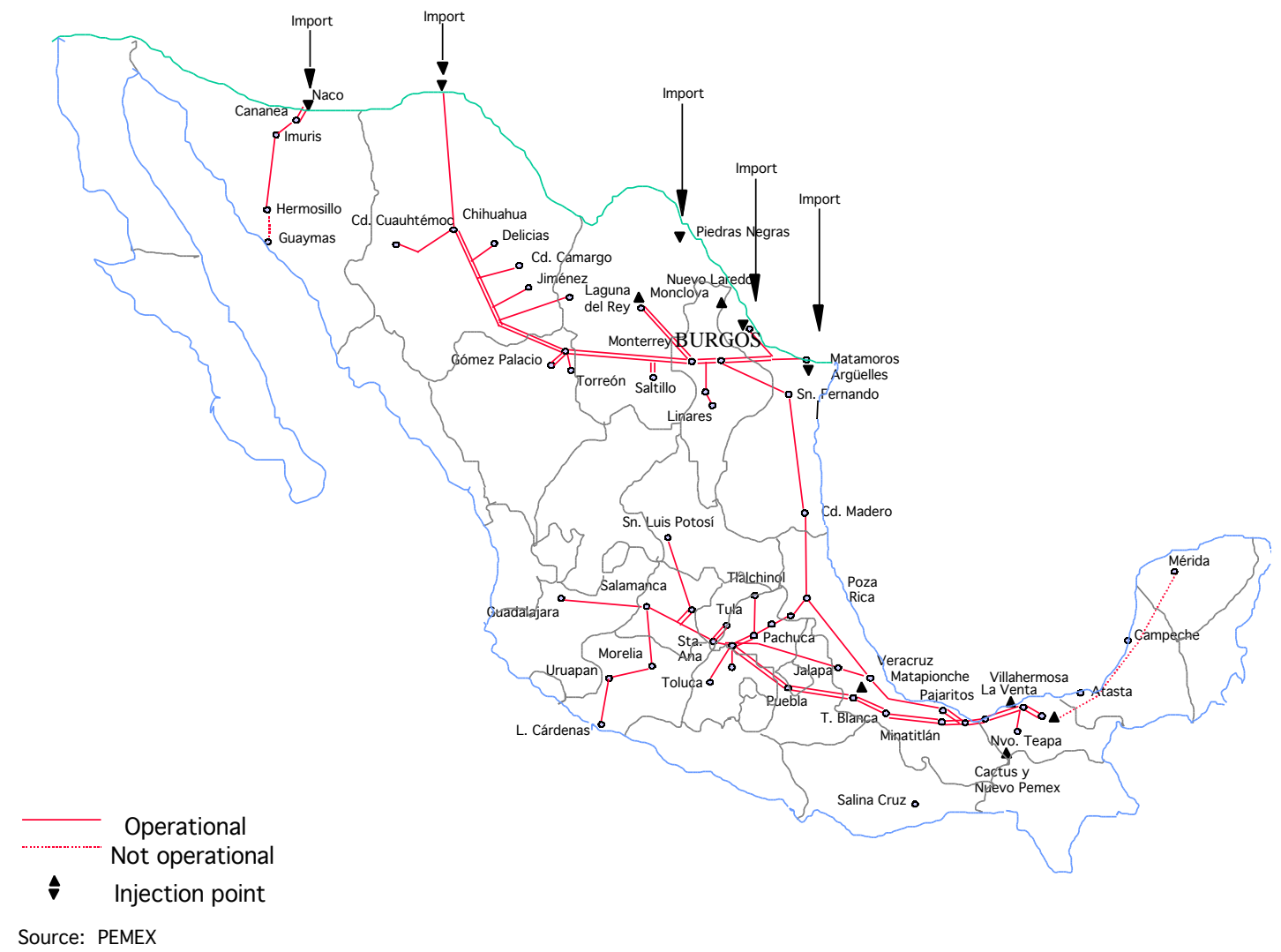

\section{Figure 1}

The Mexican pipeline system can be viewed as a pipeline connecting the production in the south with production in the north that has two branches. Ciudad Pemex is located at bottom of this pipeline. This city is located in the Southeast region where Pemex produces associated gas ( $80 \%$ of total natural gas production). In the Northeast terminal of the pipeline is Reynosa-Burgos which produces non associated gas (17.3\% of total production) and is a link with the Texas pipeline system. The Northwest branch of the pipeline connects Ciudad Juárez, which is a point where gas is imported, and Los Ramones is the junction of the Southeast, Northwest and Northeast pipelines. The Southwest branch of the pipeline connects the cities in the center of the country with the main pipeline at Cempoala.

The CRE regulates the price of gas at Ciudad Pemex through a netback formula based on a benchmark price in the Houston Ship Channel, the arbitrage point and the net transport costs. ${ }^{5}$ The point where northern and southern flows meet is defined as the arbi- 
trage point. Since the price of gas from both sources must be the same at this point, the price of the Mexican natural gas at this point is the Texas benchmark price corrected for the transport costs. The price of gas at Ciudad Pemex is the price of gas at the arbitrage point less the transport cost from this point to Ciudad Pemex. The price of gas in Mexico is then the price at the Houston Ship Channel adjusted for costs. The price cap for the Mexican natural gas is equal to the price in Houston, plus transport costs from Texas to the arbitrage point, less transport costs from the arbitrage point to Ciudad Pemex. The arbitrage point is currently located at Los Ramones.

A factor that argues for using the price of gas in Houston to price gas in Mexico is the existence of a broad market in future contracts in the Houston Market. There are important and legitimate reasons why private individuals use forward markets to reduce risk. Linking the price of gas in Mexico to the Houston market permits buyers of natural gas in Mexico to enter into transactions in these sophisticated markets to hedge for gas delivered in Mexico. This market enables gas consumers in Mexico to hedge against intertemporal risks. ${ }^{6}$ Further, many of the potential investors in power generation in Mexico have experience in using the Houston gas market. This way of pricing gas will make it easier for them to operate in Mexico. A consequence of the netback rule is to make all participants in Mexico natural gas market price takers vis-a-vis the market in Houston. Further, for all consumers the price of natural gas reflects the opportunity cost of its use.

5.See Comisión Reguladora de Energía (1996), section 4.

6. The CRE has consistently promoted price hedging along with the regulation of the price of domestic natural gas. [See Comisión Reguladora de Energía (1996 and 2000(b))] 


\section{Pricing Natural Gas: Implementing the Little-Mirrlees Rule}

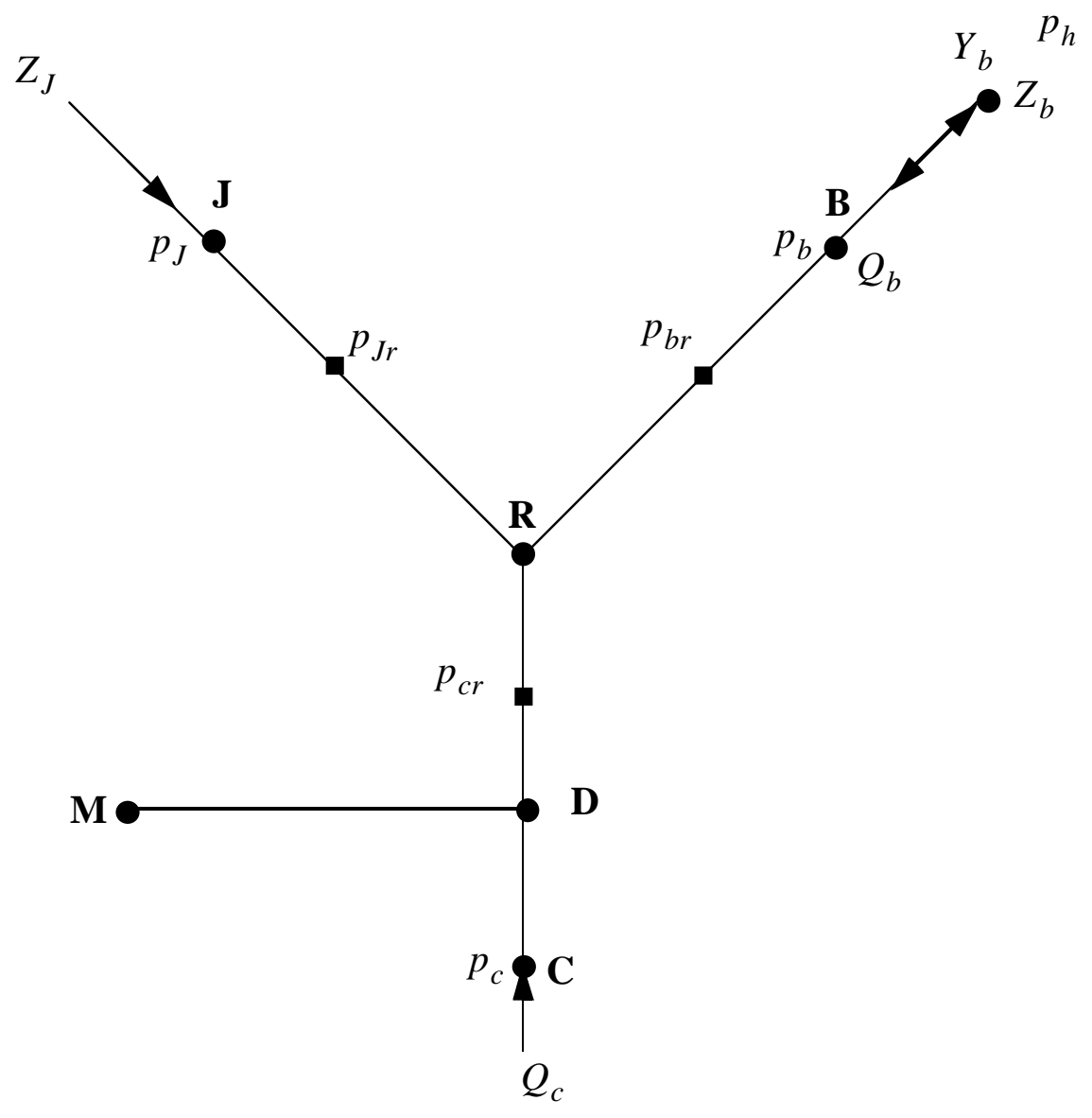

Figure 2

A model of the linkage of the natural gas pipelines to the world markets need only consider the linkages to the Texas pipeline network. Figure 2 captures the essential features of the complete Mexican gas pipeline system. $Z_{J}$ represents imports at Juárez from West Texas, $Z_{b}$ represents imports at Burgos, $Y_{b}$ represents exports at Burgos, and $Q_{b}$ represents production at Burgos. $\mathbf{R}$ is Los Ramones, the point where the main system and the northwest subsystem are physically interconnected. D is Cempoala, the point where the main system and the central subsystem are physically interconnected. Demand is distributed on the lines JR which represents demand between Juárez and Los Ramones (Monterrey is located on this line), BR between Los Ramones and Burgos, DM which represents demand in the center 
of Mexico (Mexico City, etc.) and on the line RC which represents demand south of Mexico. C is Ciudad Pemex. Gas is supplied at $\mathbf{J}, \mathbf{B}$, and $\mathbf{C}$ by the amounts $Q_{a}, Q_{b}$, and $Q_{c}$. The price at point $\mathbf{J}$ is given by $p_{j}$, at point $\mathbf{B}$ is given by $p_{b}$, at point $\mathbf{C}$, by $p_{c}$ and at point $\mathbf{R}$, by $p_{r}$. There can be an arbitrage point between $\mathbf{J}$ and $\mathbf{R}$ between $\mathbf{B}$ and $\mathbf{R}$, and between $\mathbf{C}$ and $\mathbf{R}$. The prices at the arbitrage points are denoted by $p_{j r}, p_{b r}$ and $p_{c r}$ respectively. The price at Houston is $p_{h}$ and the cost of moving gas from Houston to Burgos is $\bar{c} .^{7}$

Even in this form, the general solution of this problem is complicated. However, the problem can be simplified even further by exploiting some technical and institutional properties of the Mexican pipeline network. First, there cannot be equilibrium with three arbitrage points. This would require that point $\mathbf{R}$ be a production source. Second, the capacity of the pipeline at the arbitrage point and the demand on the JR segment of the pipeline (e.g. Monterrey) are such that gas from West Texas will not reach Los Ramones. This implies that one of the arbitrage points must be in the Juárez-Los Ramones segment of the pipeline. Since gas is produced at Burgos and Ciudad Pemex, there must be an arbitrage point delineating these two sources of production. Thus, there are two arbitrage points and one of them must be in the Juárez-Los Ramones segment of the pipeline.

This enables us the treat the problem of pricing gas on the main branch connecting Burgos with Ciudad Pemex as a single pipeline where Los Ramones and Cempoala are mass points in the distribution of demand. Once the price of gas at Los Ramones is determined, pricing gas on the Juárez-Los Ramones segment of the pipeline is simple.

The solution of this problem gives a formula for pricing natural gas on the Mexican pipeline system. The netback rule follows from the solution that minimizes the economic cost of satisfying the demand for natural gas. The shadow prices in these optimizations associated with the production of natural gas in Mexico are the prices of

\footnotetext{
7. The Houston Ship Channel is linked to the Mexican pipeline system via four U.S. pipelines (PG\&E, Tetco, Coral and Tennessee).
} 
natural gas that are optimal. Intuitively, these rules can be derived by appealing to the condition, that at the margin, Pemex should be indifferent between the sale of gas at any point in Mexico and the sale or purchase of gas in Houston. Clearly if this condition does not hold, it is possible to construct an allocation of gas that will improve welfare. It is just necessary to shift the allocation of gas from activities whose marginal benefit is less than the price of gas to activities whose marginal benefit is higher than the price of gas.

Consider a planner trying to allocate the consumption of gas in Mexico so as to maximize welfare given by

$$
W=\int_{0}^{1} v[q((n), n)] d n
$$

where $v[q((n), n)]$ is the utility of gas at point $n$.Gas is produced domestically and gas is either exported to or imported from the Houston market.

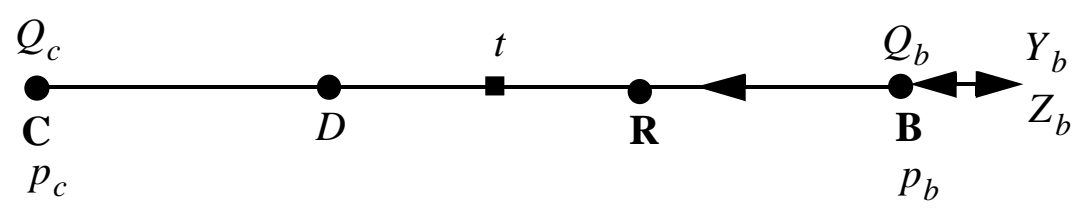

Figure 3

Let $t$ be the arbitrage point in the Ciudad Pemex- Burgos segment of the pipeline, $t=0$ is at Ciudad Pemex and $t=1$ is a Burgos. (See Figure 3). Let the demand at any point on the line B-C be given by $q(n)$. Let $n_{d}$ and $n_{r}$ be the locations of Cempoala and Los Ramones respectively. ${ }^{8}$ The choice variables are exports, $Y_{b}$, imports $Z_{b}$, the amount

${ }^{8}$ Note that because gas can be imported from Texas at Ciudad Juárez, $v\left[q\left(\left(n_{r}\right), n_{r}\right)\right]$ is actually a function of the amount of gas imported at Ciudad Juárez. Ignoring this complication does not change the result and simplifies the exposition. It is just necessary to show that the condition given by equation (10) will hold for any level of imported gas and thus will hold for the optimal level. 
of consumption and the arbitrage point $t$. The variables of interest are the arbitrage point and the price of gas at Burgos and Ciudad Pemex.

Assume that the cost of moving natural gas from point $\mathbf{C}$ to a point located at $\mathrm{n}$ is $c n$ and the cost of moving natural gas from point $\mathbf{B}$ to a point located at $n$ is $c(1-n)$. The cost of moving natural gas from Burgos to Ciudad Pemex is $c$.

The objective function of our model is then to maximize

$$
\int_{0}^{1} v([q(n)], n) d n-\int_{0}^{t} q(n) c n d n-\int_{t}^{1} q(n) c(1-n) d n-\left(p_{b}+\bar{c}\right) Z_{b}+\left(p_{b}-\bar{c}\right) Y_{b}
$$

where $\int_{0}^{t} q(n) c n d n$ is the cost of delivering gas to the arbitrage point from Ciudad Pemex. The term $\int_{t}^{1} q(n) c(1-n) d n$ is the cost of delivering Burgos gas to the arbitrage point. If $\bar{c}$ is the cost of transporting gas from Houston to Burgos, the term $\left(p_{h}+\bar{c}\right) Z_{b}$ represents the cost of imports and the term $\left(p_{h}-\bar{c}\right) Y_{b}$ represents the income from exports. The constraints are:

$$
\begin{gathered}
Q_{b}+Z_{b}-Y_{b}-\int_{t}^{1} q(n) d n=0, \\
Q_{c}-\int_{0}^{t} q(n) d n=0
\end{gathered}
$$

where equation (3) is the resource constraint at Burgos, and equation (4) is the resource constraint at Ciudad Pemex. The planner chooses imports, $Z_{b}$, exports, $Y_{b}$, the distribution of consumption, $q(n)$, and the arbitrage point, $t$. The Lagrangian is 


$$
\begin{aligned}
& L=\int_{0}^{1} v[q((n), n)] d n-\int_{0}^{t} q(n) c n d n-\int_{0}^{1} q(n) c(1-n) d n-\left(p_{h}+\bar{c}\right) Z_{b}+\left(p_{h}-\bar{c}\right) Y_{b} \\
& +\alpha\left[Q_{b}+Z_{b}-Y_{b}-\int_{t}^{t} q(n) d n\right]+\beta\left[Q_{c}-\int_{0}^{t} q(n) d n\right]
\end{aligned}
$$

where $\alpha$ is the dual associated with the value of natural gas at Burgos, $\beta$ is the dual associated with the value of natural gas at Ciudad Pemex.

The Kuhn-Tucker conditions with respect to $Y_{b}$ and $Z_{b}$ are

$$
\begin{aligned}
& p_{h}-\bar{c}-\alpha \leq 0, \quad Y_{b}\left(p_{h}-\bar{c}-\alpha\right)=0 \\
& \alpha-p_{h}-\bar{c} \leq 0, \quad Z_{b}\left(\alpha-p_{h}-\bar{c}\right)=0
\end{aligned}
$$

The Euler equations for $q(n)$ are

$$
\frac{\partial v[q((n), n)]}{\partial q(n)}-c n-\beta=0
$$

for $n<t$ and

$$
\frac{\partial v[q((n), n)]}{\partial q(n)}-c(1-n)-\alpha=0
$$

for $n \geq t$. The first order conditions with respect to $t$ under the assumption that $0<t<1$ can be written as

$$
[c t-c(1-t)-\alpha+\beta]=0 .
$$

The Kuhn-Tucker conditions (6) and (7) determine the price of gas at Burgos. Substituting equation (6) into equation (10) gives the price of gas at Ciudad Pemex. If Mexico is exporting gas then 


$$
p_{c}=p_{h}+c-2 c t-\bar{c}
$$

and if Mexico is importing gas then

$$
p_{c}=p_{h}+c-2 c t+\bar{c}
$$

and note that

$$
\frac{\partial p_{c}}{\partial t}=-2 c
$$

so a change in the arbitrage point changes the price of gas by a factor of two. Equation (9) and (10) can be solved for $\hat{q}(n)$ where the ${ }^{\wedge}$ represents the optimal solution. Note that demand for gas between Burgos and the arbitrage point is independent of the arbitrage point and depends only on the price of gas at Burgos. The price of gas at Burgos depends only on whether Mexico is importing or exporting gas.

The value of $\hat{t}$ is obtained by solving

$$
Q_{c}-\int_{0}^{t} \hat{q}(n) d n=0
$$

It should be noted that this implies that $\hat{q}(\hat{t})>0$ is a necessary condition for the arbitrage point. In practice, this suggests that the arbitrage point is likely to be either at Los Ramones or Cempoala as they are mass points in the distribution of gas consumption.

Now suppose that there is a change in the production at Burgos that does not change whether Mexico is importing or exporting gas. There is not change in the price of gas at $\hat{t}$ and $\hat{q}(n)$ is still a solution for $[0, \hat{t}]$. The price of gas and demand for gas in Mexico is independent of the production at Burgos as long as the import/export condition does not change. 


\section{Export Constraint}

The previous analysis was done under the assumption that the export of gas at Burgos was not constrained by pipeline capacity. The policy of linking the price of gas on the Mexican pipeline system to the price of gas in Houston requires that gas is able to move so that markets clear. This requires that there is sufficient investment in pipelines so that pipeline capacity does not bind. The capacity in the Mexican pipeline system and the links with the Texas pipeline system have expanded. There are forecasts that the demand for gas will grow at a rate of 10 percent a year. At that rate of growth, demand will double in less that seven years, so it is necessary to start planning if there is to be sufficient pipeline capacity so that there are not any bottlenecks. Financing this investment should not be a problem. Calculation suggest that the benefits in the form of lower prices are so large that consumers should be willing to pay transport rates that are sufficient to insure that there is adequate investment in pipelines. ${ }^{9}$

If these flows are constrained, then it is necessary to add a constraint, $\bar{Y}_{b}$, for exports at Burgos and a constraint, $\bar{Z}_{b}$, for imports at Juárez to the optimization problem. These can be written as

$$
\begin{aligned}
& \bar{Y}_{b}-Y_{b} \geq 0 \\
& \bar{Z}_{b}-Z_{b} \geq 0
\end{aligned}
$$

The Lagrangian is

$$
\begin{aligned}
& L=\int_{0}^{1} v[q((n), n)] d n-\int_{0}^{t} q(n) c n d n-\int_{0}^{1} q(n) c(1-n) d n+\left(p_{h}+\bar{c}\right) Z_{b}+\left(p_{h}-\bar{c}\right) Y_{b} \\
& +\alpha\left\lceil Q_{b}+Z_{b}-Y_{b}-\int_{t}^{1} q(n) d n\right\rceil+\beta\left\lceil Q_{c}-\int_{n}^{t} q(n) d n\right\rceil+\delta_{1}\left(\bar{Y}_{b}-Y_{b}\right)+\delta_{2}\left(\bar{Z}_{b}-Z_{b}\right)
\end{aligned}
$$

\footnotetext{
${ }^{9}$ See section 11 .
} 
where $\delta_{1}$ is the Lagrange multiplier for the export constraint at Burgos and $\delta_{2}$ is the Lagrange multiplier for the import constraint. Since the gas produced at Burgos is non-associated gas, production at Burgos can be adjusted and the only cost to Mexico is the opportunity cost of selling the gas. However, suppose that the constraint on imports at Burgos is binding. The first order condition with respect to $Z_{b}$ is

$$
\alpha=p_{h}+\delta_{2}
$$

If the amounts of gas needed to meet the demand is small Mexico's linkage with the United States gas market would be the price at Ciudad Juárez and the netback rule can be used to determine the price at Los Ramones, $p_{r}$. The price at Burgos would in turn be determined by the price at Los Ramones and the cost of moving gas from Burgos to Los Ramones,

$$
p_{b}=p_{r}-c\left(1-n_{r}\right)
$$

where $n_{r}$ is the distance from Burgos to Los Ramones. This in turn could be used to solve for $\delta_{2}$ which is the marginal cost of the capacity constraint. The differential between the price at Burgos and the Houston Ship Channel price (adjusted) would be reflected in the Lagrange multiplier associated with the capacity constraint on exports, $Z_{b}$. (See Figure 4) This multiplier reflects rents to the control of access to the pipeline. ${ }^{10}$

10. This is an example of the more general proposition that if there are pipeline bottlenecks, the Lagrange multiplier associated with the pipeline capacity constraint reflects those rents. Who captures the rents depends on institutional arrangements. 


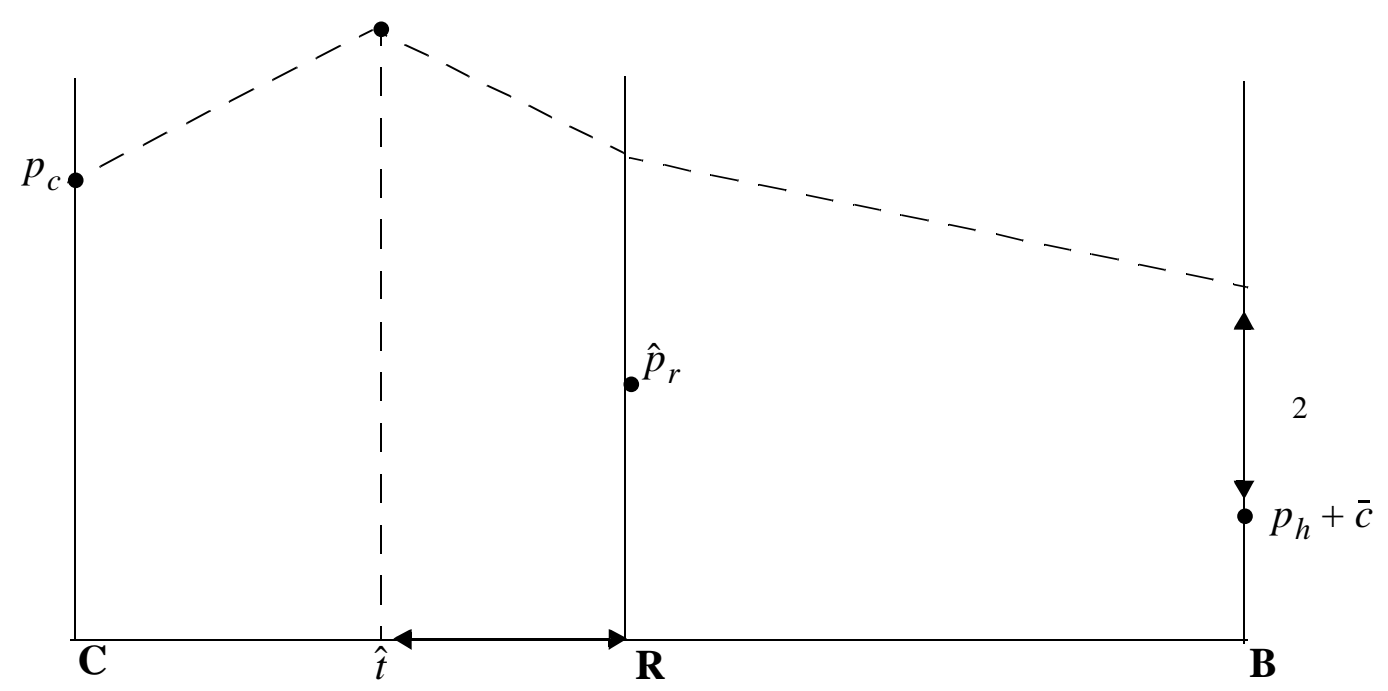

Figure 4

As long as the link between the arbitrage point is not constrained, the price at Ciudad Juárez will be a reasonable guide as the North American gas market is likely to be in equilibrium. It may be the case, however, that demand conditions are such that the pipeline system in the United States is not able to move sufficient gas to reach a market equilibrium. West Texas gas may be underpriced and this will be reflected in the price of gas in Mexico.

The pipeline from Ciudad Juárez to the West Texas fields has limited capacity and it is possible that both constraints may bind. In that case the netback rule cannot work as the flow of gas cannot equilibrate the market. There are two alternatives, gas is rationed or the price of gas is allowed to adjust and rents accrue to the scarce factor, pipeline capacity.

\section{Location of Production}

Another issue that has come up in policy discussion is the impact of the distribution of gas production on the price of gas in Mexico. Are there any welfare implications associated with the location of production or new discoveries. This question is easily answered by examining the duals for production at Burgos and Ciudad Pemex. Recall that the economic interpretation of the dual is the value of relaxing that constraint. The value of the dual at Burgos is 


$$
\alpha=p_{b}
$$

and the value of the dual at Ciudad Pemex is

$$
\beta=p_{b}+c-2 c \hat{t}
$$

Since the multiplier measures the value of the resource, if $\beta>\alpha$ it is more efficient to develop gas resources at Ciudad Pemex and if the term $\quad \alpha>\beta \quad$ it is more efficient to develop gas resources at Burgos. This depends on the sign of $c-2 c \hat{t}=c(1-2 \hat{t})$. If the arbitrage point is closer to Ciudad Pemex, $\hat{t}<\frac{1}{2}$, and the term is positive. If the arbitrage point is closer to Burgos, $\hat{t}>\frac{1}{2}$, and the term is negative.

The intuition behind this result is simple. The net benefit of a marginal unit of production is to displace one unit of gas at the arbitrage point. The production at the point nearest the arbitrage point yields the highest net social benefit.

It should be noted that if there is some flexibility in meeting domestic demands from Burgos or Ciudad Pemex, revenue maximizing behavior on the part of Pemex would shift production to Burgos as that would shift the arbitrage point south and increase the price of gas at Ciudad Pemex.

\section{Problems with flexibility in the netback rule}

The present regulations permit Pemex to sell gas at below the Houston netback price as long as they do so in a nondiscriminatory fashion. This policy is supported by the received wisdom in regulatory theory in that prohibiting a voluntary transaction on the part of two competent parties does not improve welfare ${ }^{11}$ However, this result does not apply in this case. The linkage to Houston means that all parties in the Mexican market are price takers. Since Mexican gas can always be sold in Houston, the value of the marginal cubic foot of gas at the well in Mexico is the Houston price less cost of transport. We will demonstrate that a policy to sell at the Houston netback price is Kaldor-Hicks superior to a 
policy that discount the gas in a nondiscriminatory fashion.

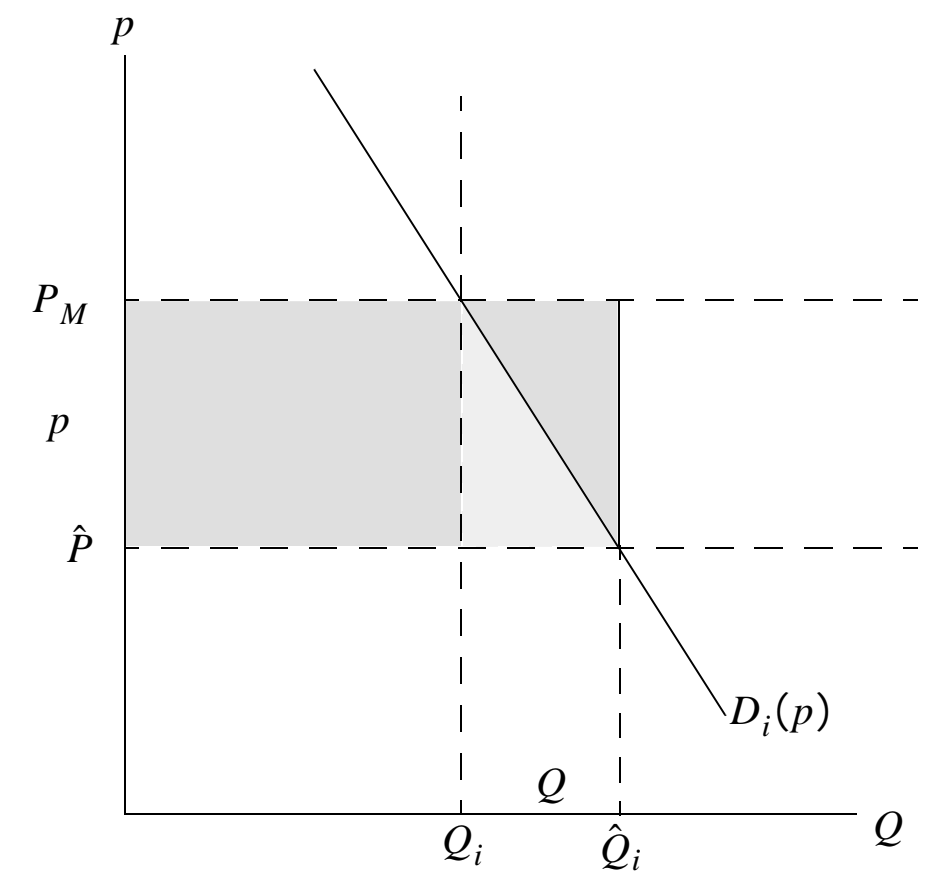

It is Kaldor-Hicks superior to have the price of gas in Mexico equal to the Houston price adjusted for transportation costs. Assume that gas is produced at Burgos and shipped to Houston and Monterrey. Let $p_{H}$ be the spot price at Houston and $p_{M}$ be the spot price at Monterrey. Let $c_{h}$ be the cost of moving gas from Burgos to Houston, $c_{m}$ be the cost of moving gas from Burgos to Monterrey. The netback rule would lead to the condition that the price of gas less transport cost is the same at Houston and Monterrey,

$$
p_{m}-c_{m}=p_{h}-c_{h}
$$

${ }^{11}$ Suppose the regulator forces the firm to charge prices $P^{0}$. Total welfare would be $V\left(P^{0}\right)+\alpha \pi\left(P^{0}\right)$. Where $\mathrm{V}$ is consumer surplus, $\pi$ is profits and $\alpha$ in $[0,1]$. If the firm is allowed to offer $P$ such that $V(P) \geq V\left(P^{0}\right)$, consumer surplus and profits increase. This alternative policy would not make consumers worse off and the firm would make a greater profit. (See Armstrong, et. al, (1994), p.67). 
Suppose a customer in Monterrey had a demand curve $Q_{i}=D_{i}(p)$ for the gas. Pemex can sell the gas to the customer in Monterrey or sell the gas in Houston. Suppose Pemex sold the consumer $\hat{Q}_{i}$ amount of gas at $\hat{p}<p_{M}$. It is feasible for Pemex to sell the gas in Houston and transfer an amount $\Delta p Q_{i}+\frac{\Delta P \Delta Q}{2}$ to the Monterrey consumer. This would lead to greater revenue, $\frac{\Delta P \Delta Q}{2}$, to Pemex and make the Monterrey consumer no worse off. Thus it is Kaldor-Hicks superior to have the price of gas in Mexico equal to the Houston netback price and sell the balance of the gas on the Houston market rather than to sell gas in Mexico at a price below the Houston netback price.

\section{Gas Marketing by Pemex}

Another policy question is what restrictions should be placed on Pemex's marketing activities in the natural gas market. To address this question, it is useful to review what are probably well accepted goals for regulation. These include the efficient allocation of resources, achieving some redistributive goals, simplicity and transparency. With these goals in mind, it is clear that the decision to link the price of natural gas in Mexico to the price at the Houston ship channel by a netback rule solves some very difficult technical and institutional problems in a very simple fashion. The netback rule links the price of gas at any point in Mexico to the price of gas in Houston adjusting for the cost of transportation. The natural gas market in Mexico then has all the properties of the gas market at Houston. In particular, all agents are price takers with respect to the market and the Houston market can be used by agents in Mexico for hedging and other forward contracts. The key to the implementation of this policy is that there is sufficient pipeline capacity so that the gas markets can clear and rents do not accrue to the pipelines. If there is not sufficient pipeline capacity so that the natural gas markets in Mexico can clear at the Houston netback prices, it is impossible to implement the netback rule. At the net back price, demand will be greater than supply. 
The reason that has been given for allowing Pemex to sell at a price below the Houston netback price, as long as the sales were non discriminatory, is that there is no reason to restrict voluntary transaction between parties. However, there is a substantial agency problem in these transactions. It is hard to understand why Pemex (acting as a agent for the Mexican people) would want to sell gas in Mexico for less that it could net by selling the gas in Houston. There may be policy reasons to subsidize gas in certain circumstances, however, this does not seem like a decision that should be delegated to Pemex gas marketing

The implementation of the netback rule, together with sufficient pipeline capacity so that gas can flow to equilibrate markets means that all participants in the Mexican gas market, including Pemex, are on equal footing as participants in the Houston Ship Channel gas market. The task of the CRE is straightforward. The Houston market can serve as a buffer for fluctuations in Pemex's production or in demand. This buffer allows Pemex to only sell "plain vanilla" gas without having to engage in complex market operations in Mexico. It it is the policy of the Mexican Government to open the energy market to the private sector as much as possible, consistent with the Constitution, then there is no need for Pemex to act as a gas marketeer in Mexico. Pemex has access to the Houston market, which has the advantage of being a well developed market. Pemex's transactions in that market would not create any regulatory issues for the CRE as long as Pemex sells gas in Mexico at the Houston spot netback price. This simple rule will result in an efficient and transparent natural gas market in Mexico. ${ }^{12}$

There are important and legitimate reasons why private oil companies use forward markets to reduce risk; let us grant that such reasons may also apply a nation oil company such as Pemex. Restricting Pemex to sell gas in Mexico at the Houston spot market netback price does not eliminate any options for Pemex. Linking the price of gas in Mexico to

12. The CRE has recently recognized the need to dismantle Pemex's vertical integration between transportation and marketing as one of the most important future tasks, (See Comisión Reguladora de Energía (2000(a))). 
the Houston market permits Pemex to operate in these sophisticated markets without involving their customers for gas delivered in Mexico. Further, buyers of natural gas in Mexico can enter into transactions in Houston without involving Pemex. Thus, there is no economic reason for Pemex has to operate as a gas marketeer in Mexico.

It may seem more efficient to permit Pemex and other parties involved to enter into such transactions directly without going through the Houston market. However, requiring such transactions to take place in the well developed Houston market reduces the possibility of fraud and also reduces the regulatory burden in Mexico.

\section{Regulation of pipeline rates}

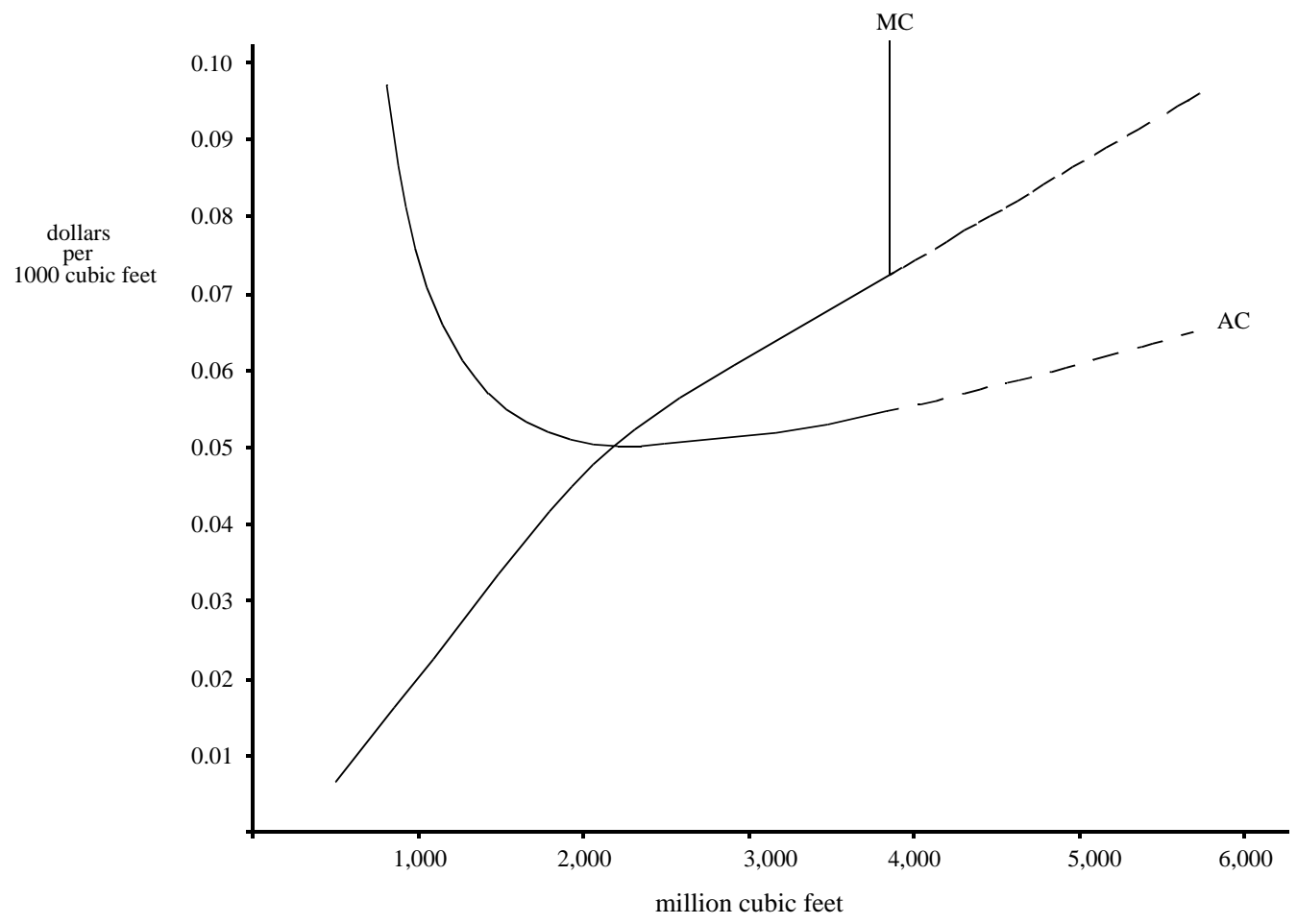

Figure 5

Pipelines have a high fixed cost, and for a substantial portion of their operating region, low marginal costs. The capacity of the pipeline is ultimately limited by the pressure limits of pipe. Figure 5 illustrates the cost curves for a 48 inch pipeline 100 miles long. ${ }^{13}$ The dashed lines represent what the cost curves would be if the pressure limits are 
not binding. At a pressure limit of 1,500 pounds per square inch, the pipeline reached its limit at approximately 3,800 million cubic feet per day. At this point it becomes impossible to increase throughput by increasing power and it becomes necessary to add compressor stations which increases throughput without exceeding the line limit by increasing the pressure gradient.

We have shown that the netback pricing rule is the solution of a static welfare optimization problem if the fee for transporting gas is the marginal cost of transporting gas. However, marginal cost pricing results in a loss or rents. (See Figure 5.) One solution to this problem is to set a fee that yields a regulated rate of return over the life of the project sufficient to cover all costs. An alternative, more sophisticated alternative is a two part tariff with a price cap. ${ }^{14}$ The sophisticated price cap mechanism is efficient in that it sets the marginal cost of transporting gas equal to the variable change for moving gas. However, this price flexibility could permit Pemex to behave strategically. The question is whether the more efficient allocation of resources merits the additional difficulties in regulation.

13. The parameters used in constructing this example are based on numbers reported in the Oil \& Gas Journal, November 27, 1995

14. CRE currently regulates Pemex transportation rate through an average revenue cap that prevails during each five year period. The initial value of average revenue $p_{0}$ is set in each period through the cost of service and adjusted by inflation, efficiency, pasthrough and correction factors. Pemex estimates its fixed, variable and financial costs (including a n 11.5 percent rate of return) and sets its two-part tariff according to its revenue requirements. (See Comisión Reguladora de Energía (1996), section 6, and Comisión Reguladora de Energía (1999)). 


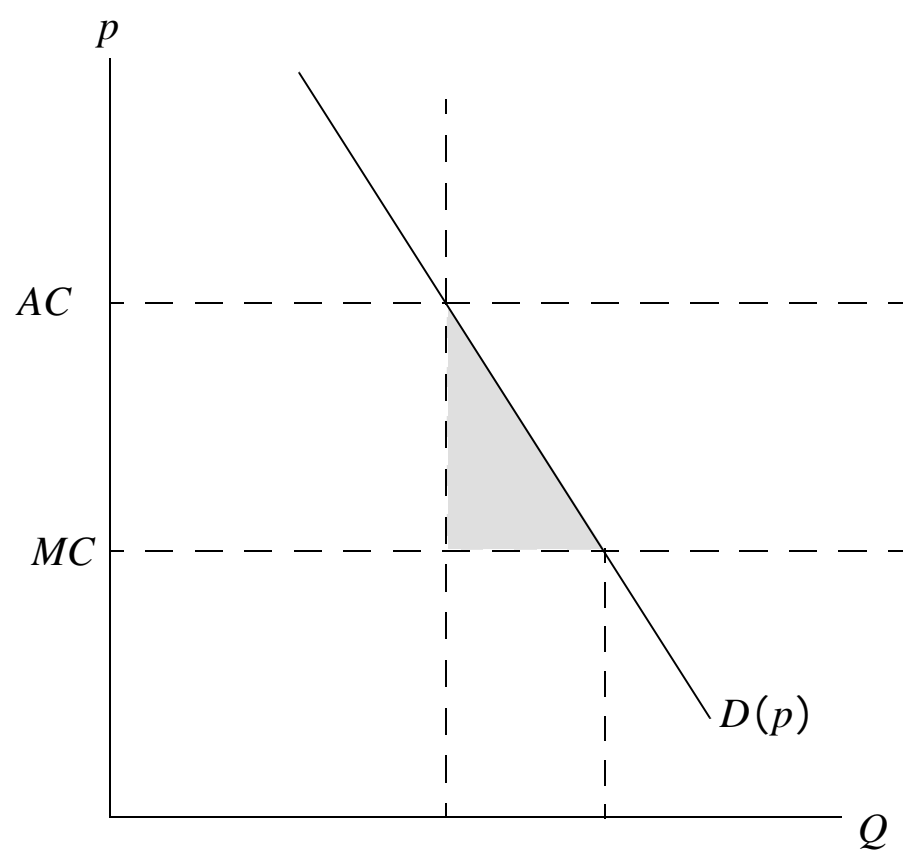

Figure 6

The shaded area in Figure 6 illustrates the welfare loss associated with using average cost rather than marginal cost in transporting gas. The loss, $L$, is given by

$$
L=-\frac{(A C-M C)^{2} Q \eta}{2 p}
$$

where $\eta$ is the elasticity of the demand for gas. Simple calculations suggest that for elasticities in the demand for gas in the range of -0.1 to -0.2 the welfare loss is of second order and can be ignored. If we calculate the dead weight loss for 4 billion cubic feet, the price of gas equal to $\$ 2.00$ per 1,000 cubic feet, an elasticity for the demand for gas equal to -0.1 , and a differential between $\mathrm{AC}$ and $\mathrm{MC}$ of $\$ 0.02$, we get that the change in demand is $4,000,000$ cubic feet and the deadweight loss is $\$ 40$. 


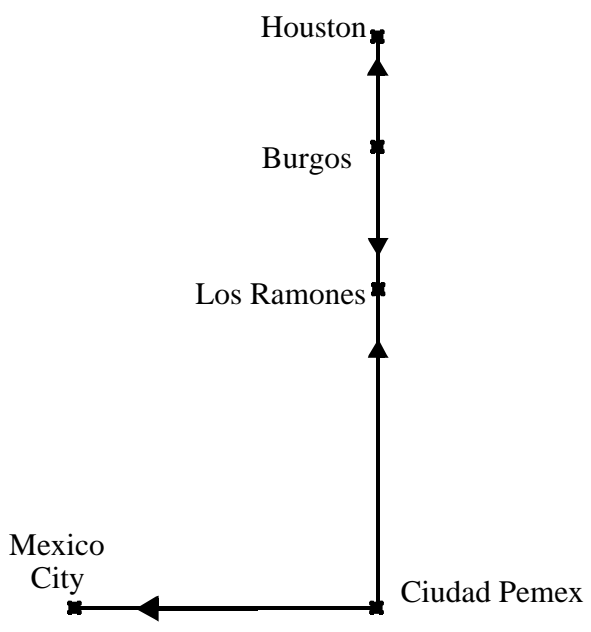

Figure 7

The welfare loss associated with using a rate of return fee structure for transport pipelines is so small that it is hard to see how the additional complexity in regulation can be justified given the low elasticity in the demand for gas in Mexico. ${ }^{15}$ A flexible pricing mechanism could permit Pemex to cross subsidize their pipeline segments through the strategic manipulation of pipeline rates. CRE could prevent such behavior by more detailed regulation, but this would increase the regulatory burden and the welfare gain from such complex pricing mechanism is very small.

A proposal that is being discussed is to change the system so that Pemex sells gas only at the point of injection. The prices in the local markets are set by local supply and demand conditions. These changes will create uncertainty in the gas market and also create the possibility of strategic manipulation of the price of gas that will be very difficult to regulate. Further, the current regulations permit the net back price to be an upper bound and Pemex can sell gas below that price if it does so in a nondiscriminatory fashion.

One advantage of using the netback rule with a fixed fee for transporting gas is that all parties act as price takers at all points along the pipeline. Restricting Pemex to sell gas

15. The Energy Ministry of Mexico estimated the following elasticities of demand for natural gas: national -.21, northwest: -0.47 , northeast: -0.13 , west -0.33 . center: -0.05 gulf:0.15. (See Secretaría de Energia, (1998) and Dahl (1992)) 
only at the point of injection and allowing local market conditions to set the price creates the possibility that marketeers could acquire some degree of market power. Parties could buy the gas at the point of injection and ship either to the Houston market (where they face an essentially flat demand curve) or to the Mexican markets where they face an inelastic demand curve. Collusive behavior on the part of marketeers would allow them to equate marginal revenue in both markets and exploit the fact that demand curves in the local markets are very inelastic and earn monopoly rents. It then becomes necessary to regulate the activities of the marketeers. The regulatory problem is much simpler if Pemex sells at all points on the pipeline system using the netback rule to determine the price. This would not eliminate other marketeers' activities.

\section{Forward Markets and Pipeline Capacity}

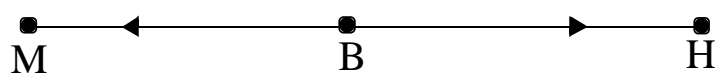

If Pemex is required to sell gas on the spot market at the Houston Ship Channel price adjusted by the netback rule, can Pemex use its monopoly power over the pipeline to get monopoly rents in this forward market? To address this question let us consider a simple model. Assume a two period model. Gas is produced at Burgos and shipped to Houston and Monterrey. Let $p_{\tau i}$ be the spot price at time $\tau$ in market $i$ and $\hat{p}_{i}$ be the forward price at time 0 in market $i ; p_{0 h}$ is the spot price at Houston a time $0, p_{0 m}$ is the spot price at Monterrey at time 0 . Prices at time 1 and forward price are defined in a similar fashion. Let $c_{h}$ be the cost of moving gas from Burgos to Houston, $c_{m}$ be the cost of moving gas from Burgos to Monterrey, and $\Delta c=c_{m}-c_{h}$. Let $\bar{Q}_{m}$ be the capacity constraint on the pipeline from Burgos to Monterrey. If the capacity constraint does not bind, the netback price at Monterrey is $p_{\tau m}=p_{\tau h}+\Delta c$. (See Figure 8 left) If the capacity constraint binds, the price at 
Monterrey is $p_{\tau m}=p_{\tau h}+\Delta c+R$, where $R$ are the rents associated with the capacity constraint. (See Figure 8 right)
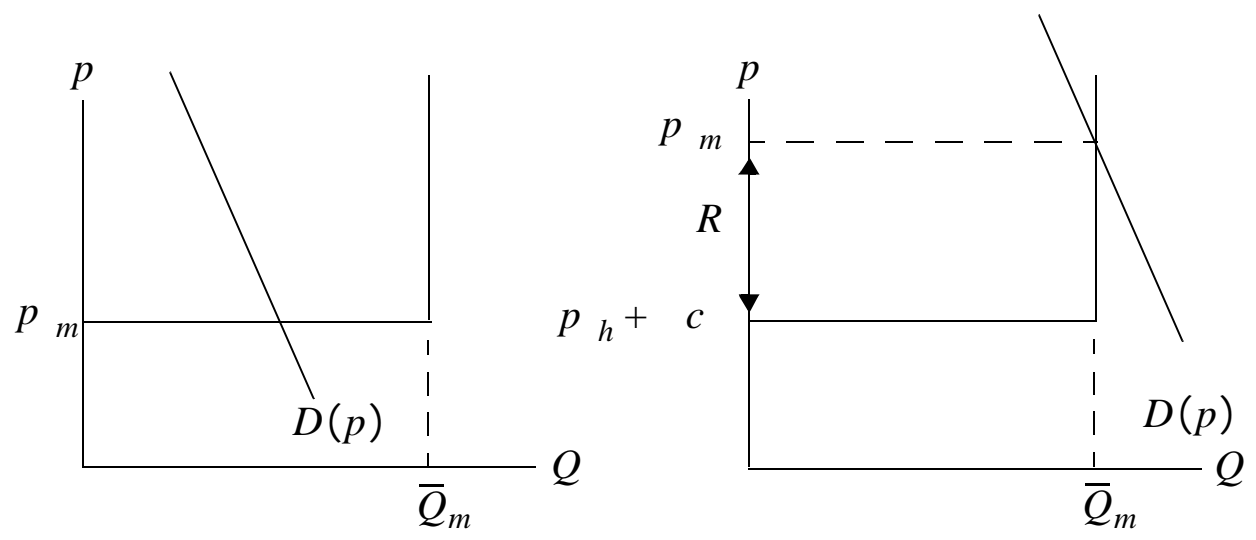

\section{Figure 8}

If the capacity constraint on the pipeline is not binding, the spot market price in Monterrey will be $p_{\tau m}=p_{\tau h}+\Delta c$. Anyone who desires to engage in forward transactions can do so in the Houston market. Pemex does not have an effective monopoly of the forward market and will capture no rents.

Suppose the capacity constraint on the pipeline is binding. In that case the spot market price in Monterrey will be $p_{\tau m}=p_{\tau h}+\Delta c+R$. Anyone who desires to engage in forward transactions can do so in the Houston market. However, Pemex can capture the rents associated with the pipeline constraint by selling output forward. Pemex can become a monopoly in the forward firm-source market. Note that rents will exist and the only question is who will appropriate them. Given that the capacity constraint on the pipeline is binding, there are no real effects.

The key regulatory issue in this context appears to be insuring that Pemex invests sufficiently in pipeline capacity so that capacity constraints are not a serious issue.

\section{Optimal Pipeline Capacity}

A necessary element in implementing a policy where the Houston gas market is the 
reference point for pricing gas in Mexico is that there is sufficient capacity so that the market for gas can always clear at the netback price. The obvious question is whether the cost of maintaining such capacity is warranted. This is a very difficult question in that there are economic, political and institutional constraints involved in the basic question of pricing gas along the Mexican pipelines.

A benchmark for discussion is the pattern of investment that would be followed by a planner that is attempting to maximize a measure of welfare. Such a policy may involve periods where the capacity constraint binds. The length of this period is a measure of the cost of the deviation from "optimal" that results from the policy of using the Houston gas market as a benchmark for pricing gas. We will show that a policy that insures sufficient capacity on the pipeline so that the gas market can clear at the Houston netback price deviates from an 'optimal" policy only by a matter of weeks.

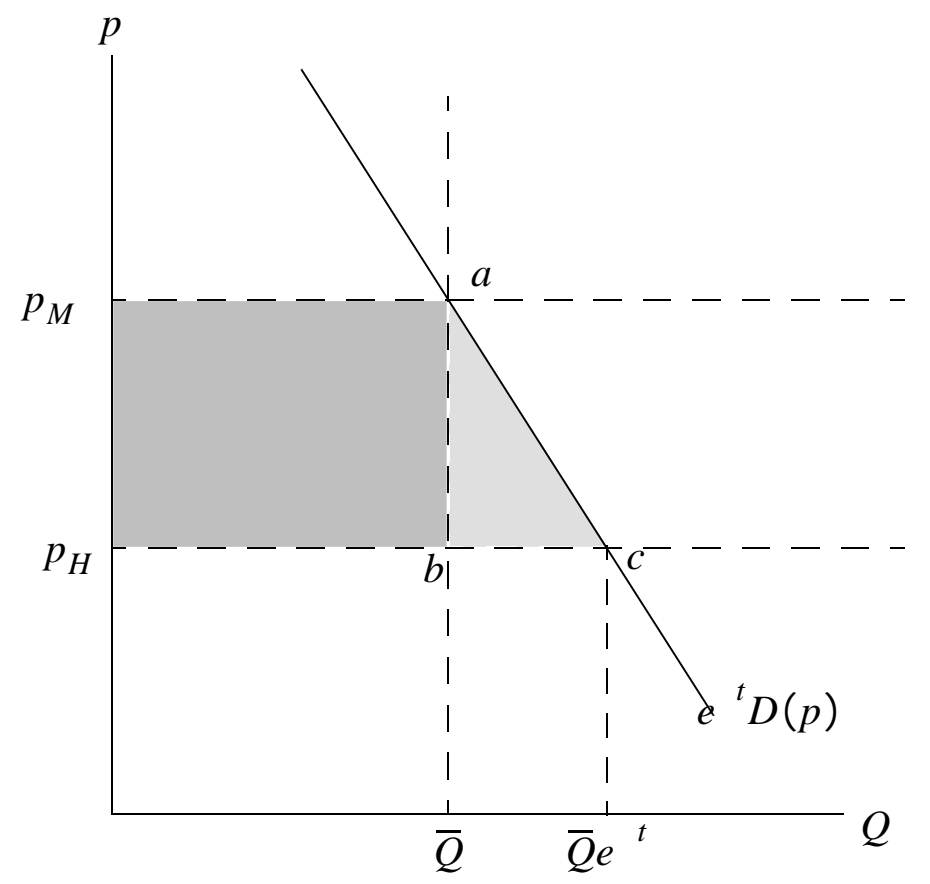

Figure 9

Let us consider a case where the pipeline capacity is given by $\bar{Q}$. Demand is grow- 
ing at a rate $\lambda$. Assume that demand reaches the pipeline capacity at $t=0$ so that $p_{M}=p_{H}$ for $Q<\bar{Q}$ and $p_{H}=\theta(\bar{Q})$. If the pipeline capacity binds, $p_{M}=\theta\left(\bar{Q} e^{\lambda t}\right)$ and the excess burden associated with this bottleneck is given by,

$$
X_{1}(t)=\frac{\Delta p \Delta Q}{2}=\frac{\bar{Q}\left(e^{\lambda t}-1\right)\left[\theta\left(\bar{Q} e^{\lambda t}\right)-p_{M}\right]}{2}
$$

This is the triangle $a-b-c$ in Figure 9. The bottleneck results in rents being generated and these rents result in the loss given by

$$
X_{2}(t)=\gamma_{1} \bar{Q} \Delta p=\gamma_{1} \bar{Q}\left[\theta\left(\bar{Q} e^{\lambda t}\right)-p_{M}\right]
$$

where $\gamma_{1}$ is a parameter that can range from 0 to 1 . This loss represents the fraction of rents that are consumed in transfer and reflects such factors as rent seeking and X-inefficiency. This is the rectangle $p_{M^{-}} p_{H^{-}}-c$ in Figure 9. Define the total loss in welfare as

$$
X(t)=X_{1}(t)+X_{2}(t)
$$

Opening a second pipeline reduces average costs of transporting gas moving the operating range of both pipelines to $\frac{Q}{2}$. The marginal cost of moving gas will be reduced by $\triangle M C$. This will reduce the cost of moving gas by $\varphi=\Delta M C \bar{Q}$. Let $\gamma_{2}$ be the weight of these cost savings in the welfare function. A welfare maximizing planner would want to pick the time of opening the second pipeline to minimize the welfare loss less the savings in operating costs which is given by

$$
\psi=\int_{0}^{T} e^{-r t}\left\{\frac{\bar{Q}\left(e^{\lambda t}-1\right)\left[\theta\left(\bar{Q} e^{\lambda t}\right)-p_{M}\right]}{2}+\gamma_{1} \bar{Q}\left[\theta\left(\bar{Q} e^{\lambda t}\right)-p_{M}\right]-\gamma_{2} \varphi\right\} d t+e^{-r T} C_{0}
$$

The first order condition for this maximization is 


$$
\left\{\frac{\bar{Q}\left(e^{\lambda T}-1\right)\left[\theta\left(\bar{Q} e^{\lambda T}\right)-p_{M}\right]}{2}+\gamma_{1} \bar{Q}\left[\theta\left(\bar{Q} e^{\lambda T}\right)-p_{M}\right]-\gamma_{2} \varphi\right\}-r C_{0}=0
$$

which can be written as

$$
\frac{\frac{\bar{Q}\left(e^{\lambda T}-1\right)\left[\theta\left(\bar{Q} e^{\lambda T}\right)-p_{M}\right]}{2}+\gamma_{1} \bar{Q}\left[\theta\left(\bar{Q} e^{\lambda T}\right)-p_{M}\right]-\gamma_{2} \varphi}{C_{0}}=r
$$

We can use our previous numerical example in Section 3 to calculate the value of $T$ for those values of the parameters and get a rough approximation of the length of the period where it is efficient for the capacity constraint to bind.

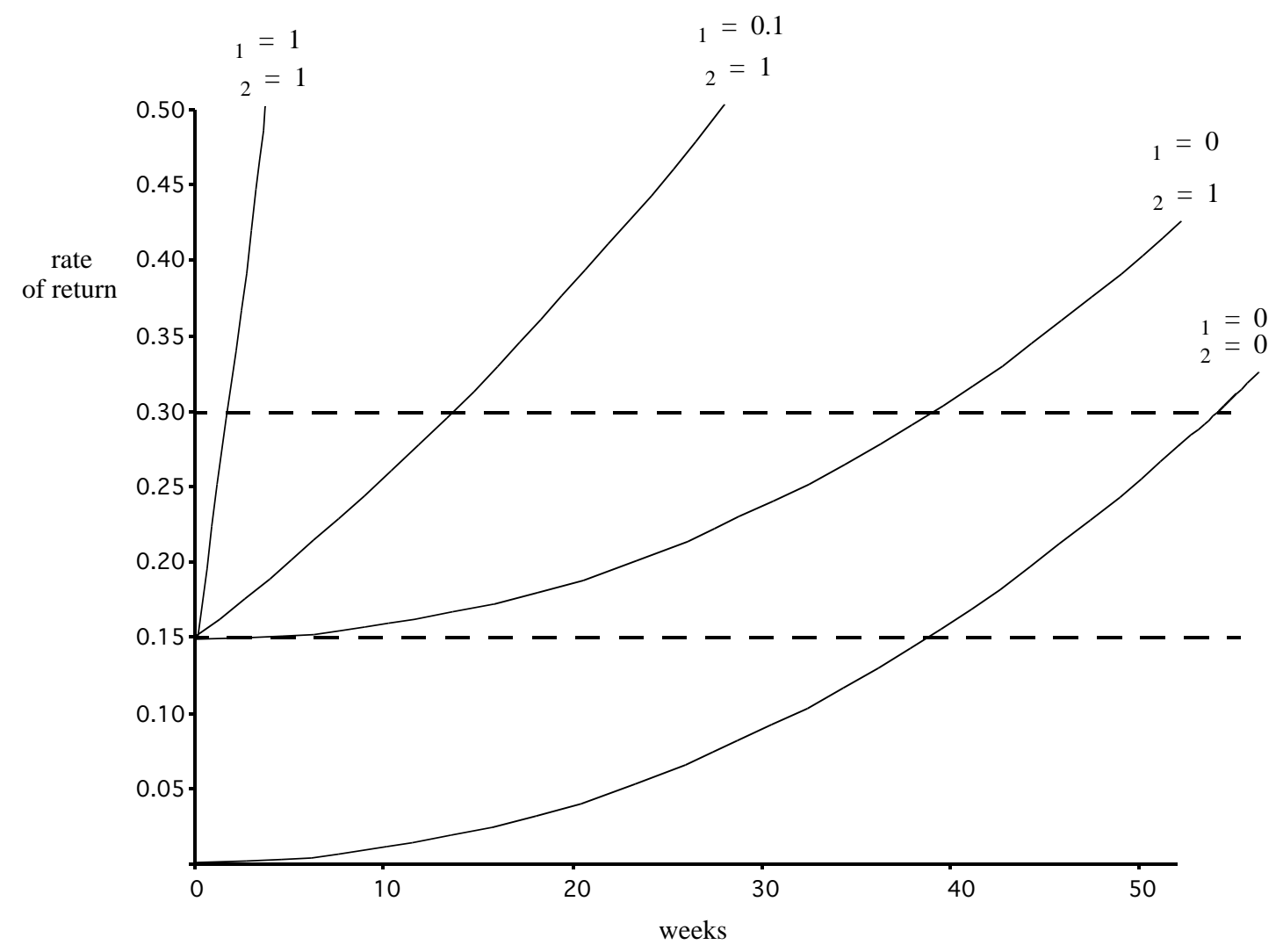

Figure 10 
Figure 10 illustrates the solution of the minimization problem for a 48 inch pipeline, 300 miles long. The curve labeled $\gamma_{1}=1, \gamma_{2}=1$ depict the loss to the consumers. If we examine the curve we see that even for a very high rate of return on the order of 30 percent, the "optimal" investment time is about two weeks after the capacity constraint begins to bind. For a rate of return of 15 percent, the consumers will never want the capacity constraint to bind. Consumers of natural gas are willing to pay for the facilities to transport the gas they demand at the Houston netback price. Thus, it is feasible to construct a rate structure that will compensate the operator of the pipeline to maintain sufficient capacity to transport the gas demanded at the Houston netback price. Note that such a policy is Pareto superior.

The curve labeled $\gamma_{1}=0.1, \gamma_{2}=1$ depict the welfare loss if we assume that 10 percent of the rents transferred to Pemex are lost to X-inefficiencies. For a rate of return of 30 percent, the "optimal" period for the capacity constraint to bind is 15 weeks. For a rate of return of 15 percent, it is not optimal for the capacity constraint to bind. The savings in operating costs are sufficient to warrant the investment.

The curve labeled $\gamma_{1}=0, \gamma_{2}=1$ ignores the transfers from consumers and includes on the savings in operating costs and the deadweight loss. The curve labeled $\gamma_{1}=0, \gamma_{2}=0$ ignores everything but the deadweight loss. Even using this measure of welfare loss the optimal period for the constraint to bind is less than one year for a rate of return of 15 percent. 


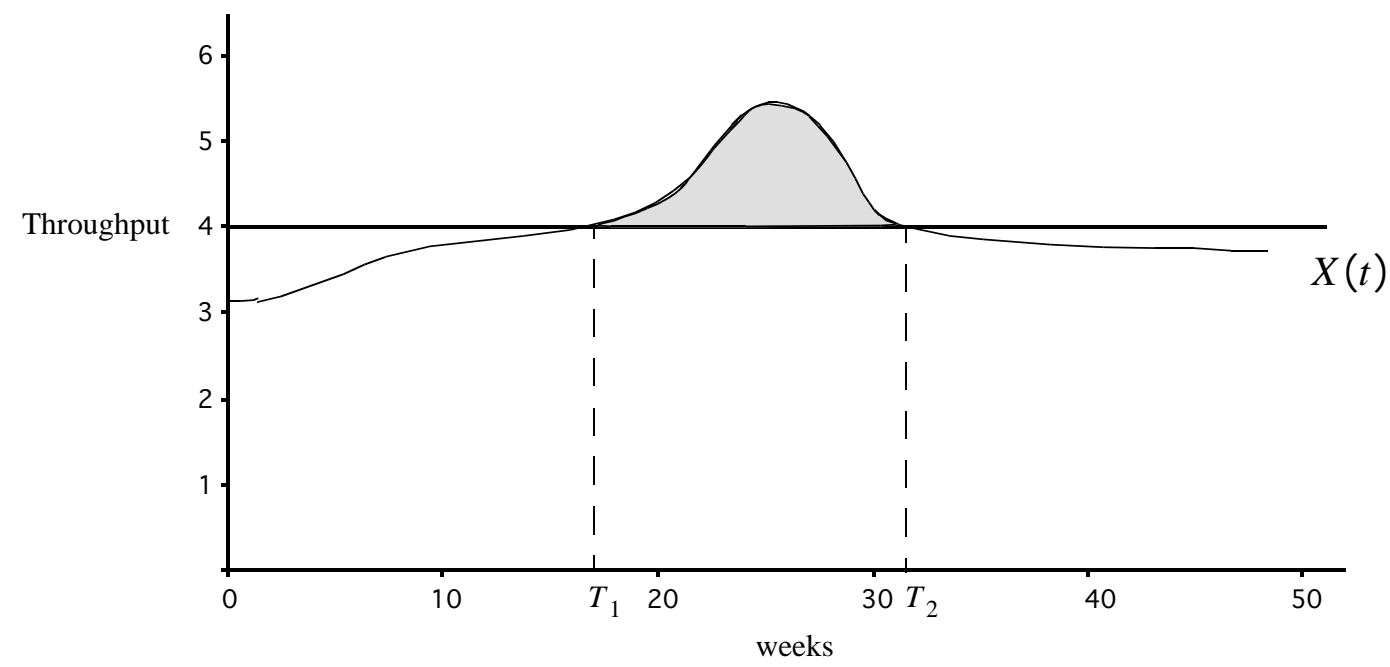

Figure 11

The weather in Mexico does not fluctuate as much as in the United States, however, there do occur peaks that could result in seasonal bottlenecks. Assume the bottleneck starts at $t=T_{1}$ and ends at $T=T_{2}$. See Figure 11.The welfare loss associated with such a bottleneck is then $\int_{T_{1}}^{T_{2}} X(t) d t$. It pays to invest in additional pipeline capacity to eliminate the bottleneck if

$$
\frac{\int_{T_{1}}^{T_{2}} X(t) d t-\gamma_{2} \varphi}{C_{0}}=\frac{\bar{X}\left(T_{2}-T_{1}\right)-\gamma_{2} \varphi}{C_{0}} \geq r,
$$

where $\bar{X}$ is the average. (See Figure 12 below) 


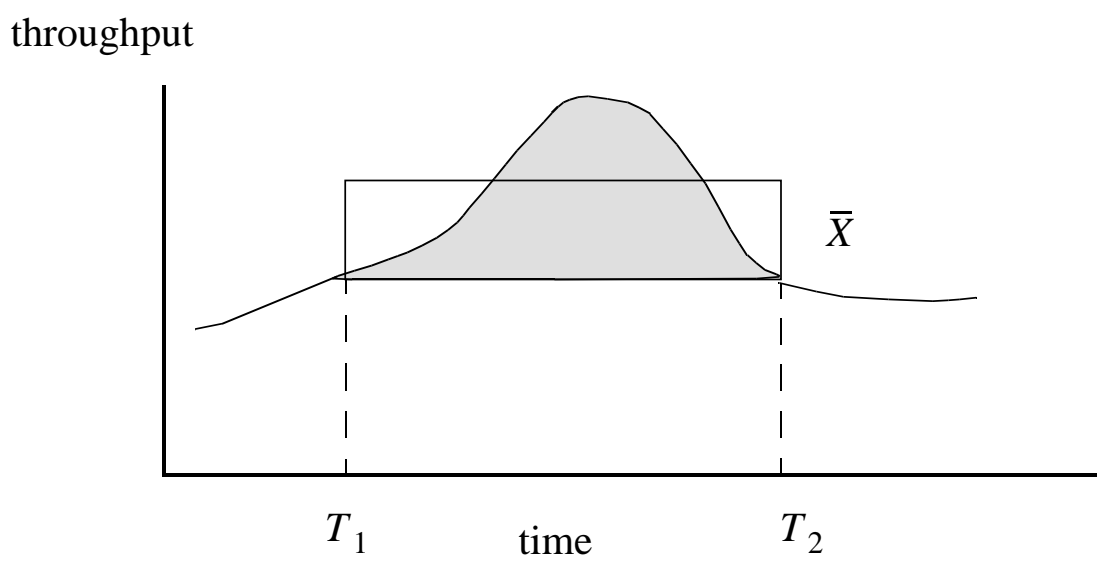

Figure 12

Let $\Delta T=T_{2}-T_{1}$, Figure 13 depicts the relationship between $\Delta T$ and $\bar{X}$ for $r=0.15$.

A

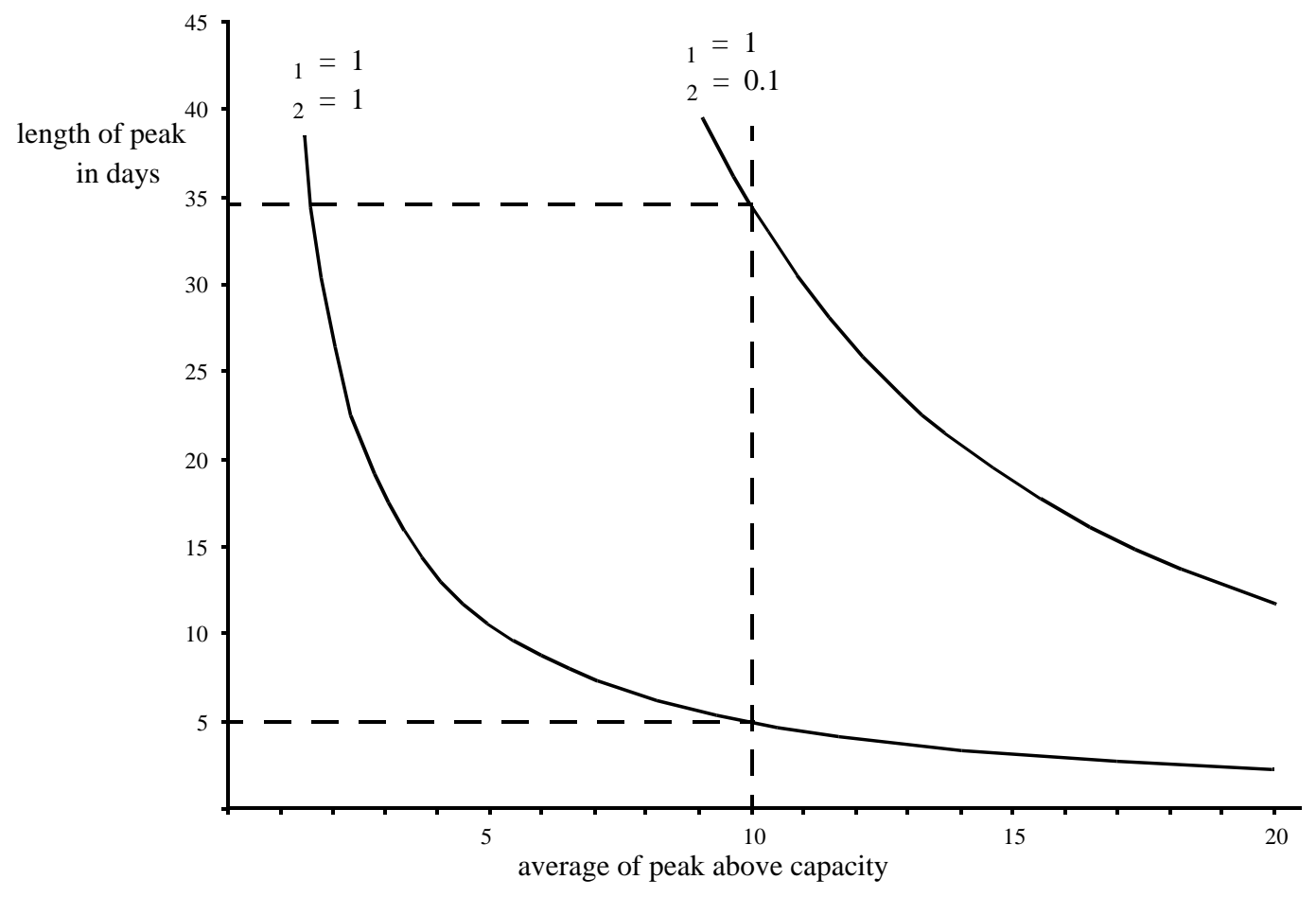

Figure 13

Consumers of gas are willing to pay to eliminate a five day peak whose average is 
10 percent over capacity.A planner that assigns a 10 percent cost to transfers will invest of eliminate a 35 day peak whose average is 10 percent over capacity.

Demand for natural gas in the Pemex transportation system will grow at an annual rate of $11.0 \%$. These estimates are based on increases in the demand for natural gas of electricity generation (annual growth rate of 19\% in 1999-2003), industrial consumers (5\%), and LDC's (4\%) (see Table 1). The northeastern and northwestern regions will register a growth of $12 \%$ and $18 \%$, respectively, during the $1999-2003$ period due to the CFE's projects. These two regions will represent $36 \%$ of total market demand.

Natural gas demand: annual growth rates by consumer type

\begin{tabular}{l|rr} 
& $1994-1997$ & $1997-2003$ \\
\hline CFE & 7 & 17 \\
Industrial & 5 & 5 \\
Cogeneration & 1 & 56 \\
Pemex & & 51 \\
Vehicles & & 13 \\
Distribution & 1 &
\end{tabular}

Table 1

Source: Escenarios de Oferta y Demanda en el Sistema Nacional de Gasoductos de Pemex-Gas, Comisión Reguladora de Energía (1999)

In 1999, demand and supply for natural gas in Mexico was 4824 and 4838 million cubic feet per day (mcfd), respectively, It is estimated that in 2000-2001 will be 5096 mcfd and $5111 \mathrm{mcfd}$, and by 2002-2003 $5259 \mathrm{mcfd}$ and $5275 \mathrm{mcfd}$, respectively. According to the permit granted by CRE to Pemex in order to transport natural gas, ${ }^{16}$ Pemex will face this increase in demand by expanding its transportation capacity (See Table 2). ${ }^{17}$

16. Comisión Reguladora de Energía (1999). This permit states all the technical details and investment plans that Pemex will have to fulfill during the next five years in its transportation activities. 
Maximum average transport capacity of Pemex' national pipeline system

\begin{tabular}{|l|c|c|c|c|c|}
\hline \multicolumn{1}{|c|}{ Units } & Year 1 & Year 2 & Year 3 & Year 4 & Year 5 \\
\hline MMGcal/year & 421.5 & 445.3 & 445.3 & 459.5 & 459.5 \\
\hline MMPCD & 4,824 & 5,096 & 5,096 & 5,259 & 5,259 \\
\hline
\end{tabular}

\section{Table 2}

Source: Comisión Reguladora de Energía (1999).

As shown, the increase of pipeline capacity will barely cope with the increase of demand, and there could be bottlenecks during peak periods. Specially important is the 1597 kilometer-long pipeline system in the Reynosa and Monterrey operating sectors where a huge increase of demand is expected and where two of the three compression stations are old. ${ }^{18}$

A very strong case can be made from these calculations that a policy that makes sure that there is always sufficient pipeline capacity so that the gas market can always clear should be followed. Such a policy would generate sufficient savings to the consumers of gas that they will be willing to pay for such investment.

17. These calculations are based on estimates of injection and extraction requirements at each node (appendix 3.1 of Pemex transportation permit), flow and capacity technical information for each transportation sector (annex 3, appendix 3.1 and 3.2), repowering needs at each compression station (appendix 3.1), and investment needs for expansion of the pipeline network (annex 6.2.1)

18. There are three compression stations located in these sectors. In the Monterrey sector there are two old reciprocating pump compression stations "Ojo Caliente", and "Santa Catarina", with more than 30 years of operation, and with huge drops in pressure and low volumes. In the Reynosa sector there is a turbine compression station constructed in 1997. 
The only argument that can be made against investing in this pipeline capacity is that the government loses the revenue created by rents to the pipeline. However, the Mexican government can at present capture the rents that would be generated by pipeline congestion by taxing gas. If we take as given that additional taxation of natural gas is not desired, then a pipeline investment policy that prevents pipeline congestion can be Pareto superior. Consumers would be willing to pay for this capacity and the only cost to the government is not collecting rents it can now collect and has chosen not to do so.

\section{Conclusions}

This paper studies the implications of the Comisión Reguladora de Energía using a netback rule based on the Houston Ship Channel price for natural gas to link the Mexican market for natural gas to the North American market. This is an implementation of the Little-Mirrlees proposal for pricing traded goods. This pricing rule means that the price of gas in Mexico is insensitive to changes in the demand for gas in Mexico. The equilibrating factor is the movement of gas. Thus, this policy is conditional of the existence of adequate pipeline capacity to transport the needed gas.

Linking the price of gas in Mexico to the Houston market permits buyers of natural gas in Mexico to enter into transactions in this sophisticated financial markets to hedge gas delivered in Mexico. Gas consumers in Mexico can hedge against intertemporal risks. Potential investors in power generation in Mexico have experience in using the Houston gas market. This way of pricing gas makes it easier for them to operate in Mexico. A consequence of the netback rule is to make all participants in Mexico's natural gas market price takers vis-a-vis the market in Houston.

The key to this policy is that there be sufficient investment in pipeline capacity so that bottlenecks do not develop. Our calculations show that a policy that makes sure that there is always enough pipeline capacity so that the gas market can always clear should be followed. That policy would result in sufficient savings to the consumers of gas that they will be willing to pay for this capacity. The only argument against investing in pipeline capacity is the loss of public revenue created by rents to the pipeline. The Mexican gov- 
ernment can at present capture these rents and does not do so. If this is the correct policy, then a pipeline investment policy that prevents pipeline congestion can be Pareto superior.

\section{References}

Adelman, M. A.,1963, The Supply and Price of Natural Gas, (B. Blackwell, Oxford).

Armstrong, M., S. Cowan and V. Vickers, 1994, Regulatory Reform, Economic Analysis and British Experience, (MIT Press, Cambridge).

Brito, D. L., W. L. Littlejohn and J.Rosellón, 2000, "Pricing Liquid Petroleum Gas in Mexico, Southern Economic Journal, 66 (3), 742-753.

Brito, D. L. and J.Rosellón, 1999, "Pricing Natural Gas in Mexico," Comisión Reguladora de Energía.(WEB SITE:http://www.cre.gob.mx)

Comisión Reguladora de Energía, 1996, "Directiva sobre la Determinacion de Precios y Tarifas para las Actividades Reguladdas en materia de Gas Natural," MEXICO. (WEB SITE:http://www.cre.gob.mx)

Comisión Reguladora de Energía, 1998 "Resolucion Sobre el Programa Temporal de Cobertura de Precios del Gas Natural para el Invierno 1998/99," RES/141/98, MEXICO. (WEB SITE:www.cre.gob.mx/registro/resoluciones/1998/res14198.html)

Comisión Reguladora de Energía, 1999, "Permiso de Transporte de Gas Natural Ortorgado a Pemex Gas y Petroquímica Básica para el Sistema Nacional deGasoductos,", Permiso Num. G/061/Tia/99 MEXICO. (WEBSITE:http://www.cre.gob.mx/registro/permisos/ gas/go61 tra99.html).

Comisión Reguladora de Energía, 2000(a), "Los Nuevos Retos de la Industria de Gas Natural. Documento Marco de la Consulta Pubica para Avanzar hacia una Estructura mas Eficientey Competitiva en la Industria del Gas Natural en Mexico," (WEB SITE:http:/ /www.cre.gob.mx).

Comisión Reguladora de Energía, 2000(b), "Resolucion que Promueve la Contratación Generalizada de Intrumentos Financieros de Cobertura de Riesgos para hacer Frente a la Volatilidad del Precio del Gas Natural," RES/148/200, Mexico," (WEB SITE:http:// www.cre.gob.mx/diario_oficial/avisos 2000-reso 0208-2000.pdf).

Dahl. C., 1992, Energy and Energy Product Demand, Elasticities for the Developing World: A Survey of the Econometric Evidence," Colorado School of Mines, Working Paper 92-14.

Little, I. M. D. and J.A. Mirrlees, 1968, Manual of Industrial Project Analysis in Developing Countries, (Development Centre of the Organization for Economic Co-Operation and Develpment, Paris)

OGS Special, 1995, Oil and Gas Journal.

Pemex, 1998, Indicadores Petroleros y Anuario Estadístico

Secretaría de Energía, 1998, "Prospectiva del Mercado de Gas Natural,1998-2007." (WEB SITE:http://www.energia.gob.mx/frame4.html) 
